\title{
Bullying and legal and illegal drug use in adolescents: a systematic review
}

\begin{abstract}
The objective was to examine the relation between bullying and legal and illegal drug use in adolescents, using data bases such as EBSCO CINAHL, EBSCO Academic Research complete, MEDLINE, Elsevier, Springer, Cochrane, PUBMED, as well as in sources of gray literature like Open Access, with the descriptors: drug abuse, drug addiction, drug dependence, bullying, cyberbullying, young adolescence, among others, in the month of October of 2016. The results obtained showed that men are the principal actors of bullying and that the aggressors in their majority are drug consumers, besides the increase in age decreases the probability of being a victim, but increases the probability of being an aggressor
\end{abstract}

Keywords: bullying, drug abuse, adolescent
Volume 3 Issue 4 - 2017

\author{
Jesica Guadalupe Ahumada-Cortez,' Mario \\ Enrique Gámez-Medina,' Carolina Valdez- \\ Montero,' Diana Moreno-Bernal' \\ 'Doctor in Nursing Science, Universidad Autónoma de Sinaloa, \\ México \\ ${ }^{2}$ Nursing Student, Universidad Autónoma de Sinaloa, México
}

Correspondence: Mario Enrique Gámez-Medina, Doctor in Nursing Science, Universidad Autónoma de Sinaloa, México,Tel 6688126405, Email mario.gamez@uas.edu.mx

Received: June 23, 2017 | Published: August 21, 2017

\section{Introduction}

Legal and illegal drug use is a public health problem that has increased as the years go by; its use, abuse, and dependence affects all society with physical, psychological, social, and school problems. Diverse studies have shown that tobacco and alcohol are initial consumption drugs and these drugs are the gateway to the consumption of other drugs like marijuana, cocaine, heroin, methamphetamines, among others. ${ }^{1-3}$

In Mexico legal and illegal drug use in the last years has increased, the Encuesta Nacional de Addictions (ENA) reported as age of onset of consumption at 13.7 years on average, which manifests that adolescents are a vulnerable group to acquire these risky behaviors, due to the fact that in this stage they find themselves in a growing need for autonomy and experimentation, where they reject adults protection and they are exposed to situations and behaviors that put them at risk; in the need of feeling special or accepted, which may lead them to believing or feeling invulnerable. ${ }^{2,4}$

According to the type of consumption the ENA reported that 2042 adolescents have consumed tobacco some time in their life, of these $68.6 \%$ started consumption out of curiosity and $24.1 \%$ by influence of the family, friends, or companion. With regards to alcohol, the pattern of typical consumption is of large quantities by consumption occasion ( 4 or more drinks by occasion in women and 4 or more drinks by occasion in men); customary consumption (consumption of at least once a week of large amounts of alcohol) by part of the adolescents is one reason of a women of 12-17 years for each 1.9 women older than 18 years. In the masculine gender: it is presented in a reason of one adolescent of 12-17 years for each five men older than 18 years. Illegal drug use in adolescents is shown in an alarming manner due to the report that $2.5 \%$ of the adolescents of $12-17$ years have consumed drugs some time in their life, referring to marihuana (2.5\%), Cocaine $(0.8 \%)$ and inhalable $(0.4 \%)$ as those of its main consumption. ${ }^{2}$

The onset of drug use is associated with diverse risk factors, within the main are found, low and high self-esteem, friends and parents that are consumers, under self-control, low school adherence, dysfunctional family relationships, curiosity, lack of religious support, Social permissiveness and accessibility., ${ }^{3,5-7}$ Recently diverse studies have documented the association between bullying and drug consumption; bullying is defined as the intentional aggression that persists in time and leads to an imbalance of power. ${ }^{8}$ In a longitudinal study carried out by Kim, Catalano, Haggerty and Abboutt ${ }^{9}$ it showed how the children that were victims of bullying were associated significantly to excessive alcohol and marihuana consumption at the age of 21. Nevertheless, other studies mention that drug consumption is an important factor to be an intimidator. ${ }^{10,11}$

In Mexico, between 20 and 32\% of the school population from 10 to 21 years old are exposed to violence, the students in elementary with an $8.8 \%$ and Jr. high scholars with a $5.6 \%$, being the constant mockery the main kind of violence practiced, followed by physical injuries and harassment. The places where these practices take place are mainly; in classrooms, in sports fields, in the patio, in the hallways, the restrooms, the cafeteria, and the streets, due to the fact that the aggressors continues to bully outside the school area. ${ }^{12,13}$

Generally the person being bullied is considered weak because of their age, sex, social class, race, ethnicity, for having different capacities or some type of social stigmatized label ("the Dummy, Lazy"), sexual orientation, religion and beliefs, among others. Bullying is accompanied by silence, by both the aggressor and the victim and the people that were witnesses; nobody does or says anything, the person being bullied lives terrified and afraid..$^{14,15}$

The aggressive behavior between students is a common and universal problem, traditionally accepted as a natural phenomenon which the majority of the time the adequate attention is not paid. Nevertheless, bullying can have immediate or late effects in general or mental health by which it is necessary to implement precautionary measures to achieve a healthy and safe social coexistence between the adolescents more than anything it requires attention for the association with substance use and abuse in adolescents as for the aggressor and the victim. Therefore, according to the established above the following objective was proposed.

\section{Objective}

Evaluate the evidence available about the relation of bullying with legal and illegal drug use in adolescents. 


\section{Method}

The process of synthesis of the literature was carried out based on the proposed model by Cooper, ${ }^{16}$ which is divided into seven steps that contemplate: the formulation of the problem, la search for literature, gather the information of the studies, the evaluation of the quality of the studies, analyze and integrate the results, interpret the evidence and present the results.

The search for the literature was done based on the publications made in the last 10 years, from January 2006 to 2016. The location of the publications was done in the month of October in the following data bases: EBSCO CINAHL, EBSCO Academic Search Complete, MEDLINE, Elsevier, Springer, Cochrane, PUBMED, as well as in sources of gray literature like Open Access, mainly collecting correlational and prospective studies with the following descriptors taken from MeSH (Medical Subject Headings): drug abuse, drug addiction, drug dependence, drug habituation, drug usage, drug use disorders, substance dependence, substance use disorder, organic mental disorders, substance- induced, substance abuse, substance addiction, substance dependence, substance use disorder, bullying, cyber bullying, young, adolescence, adolescent and teen.

The main criterion of inclusion in the studies was the relation of bullying cyber bullying and legal and illegal drug use in adolescent of both genders. To select the studies first the reading of the titles was done, second the reading of the abstract was done on the studies selected, where the studies that met with the criteria of inclusion were identified and finally the critical reading of the complete text was done, where a table of evaluation of bias was designed by the investigators Annex 1.

Annex I Table of evaluation of bias.

\begin{tabular}{|c|c|c|c|c|c|c|}
\hline \multicolumn{7}{|l|}{ Evaluation of Bias } \\
\hline Characteristics & & EI & E2 & E3 & E4 & E5 \\
\hline \multicolumn{7}{|l|}{ Probabilistic Sample } \\
\hline \multirow{4}{*}{ Size of the sample } & Potential & & & & & \\
\hline & Effect & & & & & \\
\hline & Confidence Interval & & & & & \\
\hline & Non- Response cup & & & & & \\
\hline \multicolumn{7}{|c|}{ The congruence of the independent variable at the beginning and at the end of the study } \\
\hline \multirow{3}{*}{ Clarity of the criteria } & Inclusion & & & & & \\
\hline & Exclusion & & & & & \\
\hline & Elimination & & & & & \\
\hline \multirow{2}{*}{ The instrument reports } & Alfa of Cronbach & & & & & \\
\hline & Validity & & & & & \\
\hline Reliability in the collectio & & & & & & \\
\hline
\end{tabular}

In this table of evaluation of bias the following sections were included: characteristic of the sample, size of the sample, potential, effect, confidence interval, non-response cup, the congruence of the independent variables at the beginning and at the end of the study, clarity in the criteria of inclusion, exclusion and elimination, the alpha reported for the instrument and its validity, reliability in the collection of data in addition to the congruence between the hypotheses and the objectives.

The flow chart of QUORUM (Quality of Reporting of Metaanalyses) is presented below, where the technique of selection of the studies included in the revision is shown Figure 1.

\section{Results}

From the 23 studies analyzed the results were classified in two forms, the first one referenced the type of actor (aggressor or victim) and drug consumption Table 1 and the second one is by gender and relation with the type of actor in bullying Table 2.

According to the studies analyzed by Luke et al. ${ }^{17}$ victimization is associated positively with substance use in men and in both men and women. In women's case it was found depression as a mediating role in the association between victimization and substance use.

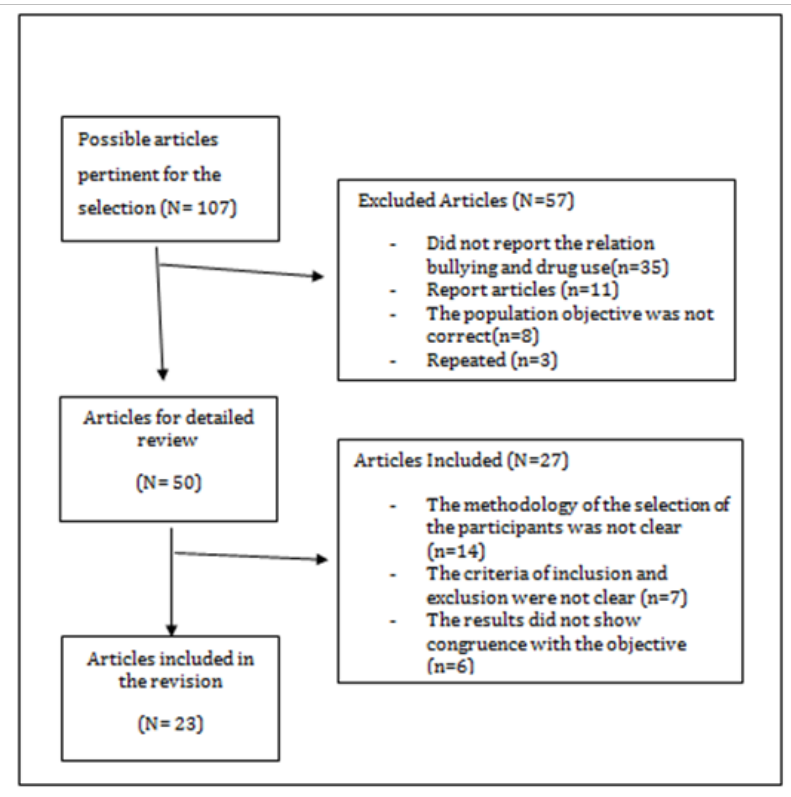

Figure I QUORUM/Selection of the studies. 
Table I Actor and drug consumption

\begin{tabular}{|c|c|c|c|c|}
\hline \multirow{2}{*}{ Authors/year } & \multirow{2}{*}{ Population/sampling } & \multirow{2}{*}{ Actor } & \multicolumn{2}{|l|}{ Drug } \\
\hline & & & Legal & Illegal \\
\hline $\begin{array}{l}\text { Wright } \\
\text { EEUU }^{18}\end{array}$ & 867 eighth grade students (middles school) & Victim & *Alcohol & *Marihuana \\
\hline Ringwalt et al. ${ }^{19}$ EEUU & $\begin{array}{l}53,750 \text { middle school and high school sixth, seventh and } \\
\text { eighth grade students }\end{array}$ & Victim & *Alcohol & $\begin{array}{l}\text { *Marihuana } \\
\text { *Inhalants }\end{array}$ \\
\hline Luk et al. ${ }^{17}$ EEUU & I,495 tenth grade students & Victim & $\begin{array}{l}\text { *Alcohol } \\
\text { *Tabaco }\end{array}$ & *Marihuana \\
\hline Mitchell et al. ${ }^{20}$ EEUU & $\mathrm{I}, 50 \mathrm{I}$ adolescents from $10-\mathrm{I} 7$ years of age & Victim & $\begin{array}{l}* \text { Alcohol } \\
* \text { Tobacco }\end{array}$ & $\begin{array}{l}\text { *Marihuana } \\
\text { *Inhalants } \\
\text { *Medication }\end{array}$ \\
\hline Morris et al. ${ }^{21}$ & 3,312 adolescents from $14-16$ years of age & $\begin{array}{l}\text { Aggressor } \\
\text { Victim }\end{array}$ & $\begin{array}{l}\text { *Alcohol } \\
\text { *Tobacco } \\
\text { *Alcohol }\end{array}$ & \\
\hline Kim et al. ${ }^{9}$ EEUU & 518 youths with a median age of 21.52 & Victim & *Alcohol & *Marihuana \\
\hline Fleming et al. ${ }^{22}$ Virginia, EEUU & $\begin{array}{l}\text { 104,614 (19 countries) Adolescents from 13- } 15 \text { years of } \\
\text { age }\end{array}$ & Victim & $\begin{array}{l}* \text { Tobacco } \\
* \text { Alcohol }\end{array}$ & *Drugs \\
\hline Toppe et al. ${ }^{23}$ & 324 students of high school & Victim & *Alcohol & \\
\hline Azadga ${ }^{24}$ Canada & 28,843 eighth grade students & $\begin{array}{l}\text { Victim } \\
\text { Aggressor } \\
\text { A-V }\end{array}$ & *Tobacco & \\
\hline Carmona-Torres et al. ${ }^{25}$ & 960 students (adolescents) & Aggressor & $\begin{array}{l}* \text { Alcohol } \\
* \text { Tobacco }\end{array}$ & $\begin{array}{l}\text { *Cocaine } \\
\text { *Marihuana } \\
\text { *MDMA }\end{array}$ \\
\hline $\begin{array}{l}\text { Harlow et al. }^{26} \\
\text { New Jersey-Texas, EEUU }\end{array}$ & 1,002 students from $6,8,10$ y 12 grade & Victim & *Alcohol & *Any drug \\
\hline Luukkonen, et al. ${ }^{27}$ & 508 adolescents from 12-17 years of age & Victim & $\begin{array}{l}* \text { Tobacco } \\
* \text { Alcohol }\end{array}$ & $\begin{array}{l}\text { *Marihuana } \\
\text { *Hard drugs }\end{array}$ \\
\hline McKenna et al." & 5.807 students from middle and Ir. high school & Aggressor & *Alcohol & *Any drug \\
\hline Massachusetts, EEUU & & Victim & *Alcohol & *Any drug \\
\hline Kelly, et al..$^{28}$ Conrod \& Teeson, & $588 \mathrm{Ir}$ Hiah schenl ctudentc & $A-V$ & *Tobacco & *Marihuana \\
\hline Australia & I,J00 Jr. חign school students & Aggressor & *Alcohol & \\
\hline Méndez et al 10 & 886 Ir High scheol students & Aggressor & $\begin{array}{l}* \text { Alcohol } \\
* \text { Tobacco }\end{array}$ & $\begin{array}{l}\text { *Marihuana } \\
\text { *Cocaine }\end{array}$ \\
\hline 10 & oov jr. right scrioor scudents & Victim & $*$ Alcohol & $\begin{array}{l}\text { *Marihuana } \\
\text { *Cocaine }\end{array}$ \\
\hline Hertz et al. ${ }^{29}$ EEUU & 13,846 ninth and tenth grade students & Victim & $\begin{array}{l}* \text { Alcohol } \\
* \text { Tobacco }\end{array}$ & *Any drug \\
\hline Forster et al. ${ }^{30}$ EEUU & I,I67 ninth grade students & Victim & *Tobacco & \\
\hline Litwiller et al. ${ }^{31}$ EEUU & 4,693 high school students & Victim & $\begin{array}{l}* \text { Alcohol } \\
* \text { Tobacco }\end{array}$ & *Any drug \\
\hline Luk et al. ${ }^{32}$ EEUU & 7,508 students from 6 th to 10 th grade & Aggressor & $\begin{array}{l}* \text { Alcohol } \\
* \text { Tobacco }\end{array}$ & *Marihuana \\
\hline Niemelä et al. ${ }^{33}$ Finlandia & 2,946 I8 year old adolescents & Victim & *Tobacco & \\
\hline Russell et al. ${ }^{34}$ EEUU & $\begin{array}{l}245 \text { Youth from } 21-25 \text { years, } 13-19 \text { years who have } \\
\text { suffered bullying }\end{array}$ & Victim & $\begin{array}{l}\text { *There was no } \\
\text { relation }\end{array}$ & $\begin{array}{l}\text { *There was no } \\
\text { relation }\end{array}$ \\
\hline Sullivan et al. ${ }^{35}$ EEUU & 276 jr. High school students & Victim & $\begin{array}{l}* \text { Alcohol } \\
* \text { Tobacco }\end{array}$ & *Marihuana \\
\hline Tharp-Taylor et al. ${ }^{36}$ EEUU & $\begin{array}{l}926 \text { adolescents from I I- I } 4 \text { years old from a jr. high } \\
\text { school }\end{array}$ & Victim & $\begin{array}{l}\text { *Alcohol } \\
* \text { Tobacco }\end{array}$ & $\begin{array}{l}\text { *Marihuana } \\
\text { *Inhalants }\end{array}$ \\
\hline
\end{tabular}


Table 2 Sex and bullying position

\begin{tabular}{|c|c|c|c|c|c|}
\hline \multicolumn{6}{|l|}{ Sex and bullying position } \\
\hline Authors/Year & Population/Sample & Sex & Aggressor & Victim & A-V \\
\hline Fleming et al. EEUU ${ }^{22}$ & $\begin{array}{l}\text { 104,614 (19 countries) Adolescentes } \\
13-15 \text { años }\end{array}$ & Men & & $*$ & \\
\hline Luk, Wang et al. ${ }^{32}$ EEUU & 7,508 sixth and tenth grade students & Men & $*$ & & \\
\hline Luk, Wang et al. EEUU ${ }^{17}$ & I,495 tenth grade students & $\begin{array}{l}\text { Men } \\
\text { Women }\end{array}$ & & * & \\
\hline $\begin{array}{l}\text { McKenna } \\
\text { Massachusetts, EEUU"' }\end{array}$ & $\begin{array}{l}5,807 \text { Intermediate nd jir. High school } \\
\text { students }\end{array}$ & Men & & & * \\
\hline Méndez et al. ${ }^{10}$ & 886 jr. High school students & Men & $*$ & $*$ & $*$ \\
\hline Morris et al. ${ }^{21}$ & $3,3 \mid 2$ I4-16 year old adolescents & $\begin{array}{l}\text { Men } \\
\text { Women }\end{array}$ & $*$ & & $*$ \\
\hline $\begin{array}{l}\text { Sullivan et al. }{ }^{35} \\
\text { EEUU }\end{array}$ & 276 Jr. High school students & Men & & $*$ & \\
\hline Tharp-Taylor et al. ${ }^{36}$ EEUU & 926 I I- I 4 jr. High school students & Men & & $*$ & \\
\hline
\end{tabular}

Note:*=Relation

Mitchell et al. ${ }^{20}$ found that the victims of bullying informed having consumed 3 or more legal substances, also the victims of online violence (internet/cyber bullying) and not online (harassment) have twice as more probabilities to report consumption than those who did not present violence. The victims that only reported violence online have 2.6 more probability to report substance consumption.

It was also found that either men or women smoker have a higher possibility of being an aggressor and a less probability of being victims in comparison to those who are non-smokers, in addition to that as the age increases the probability of being an aggressor increases. ${ }^{21}$ Azagba reported that the students involved in bullying have 1.48 times more provability of consuming tobacco than those who are not involved in bullying. Likewise, it is mentioned that the aggressors (bully) $(\mathrm{OR}=1.93,95 \% \mathrm{Cl}=1.42-2.63)$, the victims $(\mathrm{OR}=1.31,95 \% \mathrm{Cl}=1.14-$ $1.50)$ and the bully-victims $(\mathrm{OR}=1.75,95 \% \mathrm{Cl}=1.45-1.67)$ have a higher possibility of consuming tobacco. ${ }^{24}$ On the other hand Kelly found that the consumption of marihuana increased the possibility of being a victim of bullying and the consumption of alcohol reduces the probability of being a victim. Also the consumers of alcohol increased the probability of being an aggressor (bully) and the consumers of tobacco and marihuana increased the probability of becoming a bullyvictim. $^{28}$

Kim et al. ${ }^{9}$ from their part they found that the youth that were intimidated in their childhood were associated with the risk in developing violent behaviors or with behavior problems in late ages and with the substance use like alcohol and marihuana in excessive form, unlike in the study conducted by Niemelä et al. ${ }^{23}$ they found that children that were victims of bullying in their childhood was only related to daily tobacco consumption and in large quantities.

In relation to sex it was found that boys have a higher possibility of being intimidated in comparison to girls and this at the same time have a higher probability of developing risky behaviors..$^{22,26,36}$ Other studies agreed with these findings but also it was referred that men are more likely to be abusers and victims. ${ }^{10,11,21}$

Litwiller et al. ${ }^{31}$ reported that physical bullying obtained a positive significant relation with substance use, violent behavior, sexual behavior, and suicide behavior. In the examination of the portion of the mediate effects it showed that $50 \%$ of the total effect of physical bullying in the suicide behavior was mediated by substance use and violent behaviors. ${ }^{31}$

Carmona-Torres et al. ${ }^{25}$ reported that the aggressor presented a significant alcohol, tobacco and marihuana consumption. Méndez et al., ${ }^{10}$ found that the aggressors referred a polyconsumption of drugs like alcohol and marihuana or alcohol and cocaine, this without having spent more than two hours since the consumption from one to another, also they referred that the majority of the times that they had been involved in a fight or physical aggression they had consumed alcohol or marihuana.

Hertz et al. ${ }^{29}$ found that the women were more susceptible to being victims of bullying in persona and cyberbullying and men presented a greater bullying in person. In relation with having suffered bullying in person it was associated with tobacco, alcohol, or some type of illegal drug us, similar patterns in men and in women. In relation to women who have been victims from the two types of bullying this aggression was associated with alcohol consumption and having been a victim of bullying in person was associated with illegal drug consumption.

The excessive tobacco use daily and alcohol consumption in boys and girls is associated with being a victim of bullying, in girls the victimization was associated with marihuana and hard drug consumption, in boy's physical aggression was associated with higher alcohol consumption. ${ }^{10,11,27,35}$ Tobacco consumption was associated significantly with being a victim according to the study reported by Forster et el.. ${ }^{30}$ In another study made by Ringwalt et al. ${ }^{19}$ in 2012, found that being a victim of bullying was related with alcohol consumption, binge drinking, marihuana, inhalants between others drugs during the next 30 days. ${ }^{19}$

Wright $^{18}$ found that the victims of cyberbullying were related to alcohol use and the consumption of any drug other than marihuana, cocaine, heroin, inhalants, or prescribed drugs. Luke et al..$^{32}$ found that the adolescents that presented a lower level of maternal knowledge had a higher probability of being consumer of substances $(\mathrm{OR}=2.81)$ and of being bullies $(\mathrm{OR}=1.87)$, compared with those that reported a 
higher level of maternal knowledge. Likewise, it was found that those adolescents with less paternal knowledge had a higher probability of being consumers of substances $(\mathrm{OR}=2.39)$ and being bullies $(\mathrm{OR}=1.61)$ compared to those who had a higher level of paternal knowledge. Lastly it was found that those adolescents that spend more time with their friends had a higher probability ah consuming substances $(\mathrm{OR}=2.62)$ and being bullies $(\mathrm{OR}=1.41) .{ }^{17}$ According to Topper et al. ${ }^{23}$ a significant correlation was shown in victimization related to the score on alcohol problem (fights, personality changes, bad acts, etc.) and the same results were presented 12 months after. ${ }^{23}$

\section{Conclusion}

By the analysis of the diverse studies it can be conclude that bullying takes place especially in the masculine gender, these are more likely take part in both roles in this type of violence, also that the majority of the aggressors consume drugs and the older the less probability of being a victim, but higher is the probability of becoming an aggressor. Being a smoker increases the probability of becoming an aggressor being men or women.

Being a victim increases notably the legal and illegal drug use, especially alcohol, tobacco and marihuana consumption, but with a tendency of consuming inhalants and cocaine, this last one belonging to hard drugs. It's important remark that violence is not a game, although, in many occasions who practices or who receives it naturalizes or demerits this form of violence that this acts are considered a game, a joke, or amusing, this is why it's necessary to learn how to identify it to be able to put a stop to this types of risk behaviors.

It is necessary that the following investigations add or explain in a more specific manner the type of violence practiced and describe the different actors and not just report the victim, it is important to determine the aspects that surround this problematic to be able imply or reconstruct programs of prevention for this social phenomenon that is increasing and be able to avoid short and long term complications in children and adolescents.

\section{Acknowledgements}

This investigation was carried out with the support and financing of the National science and technology council (CONACyT), through the postgraduate scholarship.

\section{Conflict of interest}

The author declares no conflicts of interest.

\section{References}

1. Armendáriz GNA, Rodríguez AL, Guazmán FFR. Efecto de la autoestima sobre el consumo de tabaco y alcohol en adolescentes del área rural de Nuevo León, México. Rev Electrónica en Salud Ment Alcohol y Drog. 2008;4(1).

2. Encuesta nacional de adicciones. Consejo Nacional contra las Adicciones. México; 2011.

3. Cid-Monckton P, Pedrao luiz J. Factores familiares de riesgo y de protección para el consumo de drogas en adolescentes. Rev Lat Am Enfermagem. 2011;19:738-45

4. Bolaños-Gil HL, Mello DF, Ferriani M das GC, et al. Opiniones de los adolescentes escolares sobre consumo de drogas: un estudio de caso en Lima, Perú. Rev Latino-Americana Enferm. 2008;16:551-557.
5. Díaz NB, García-Aurrecoechea R. Factores psicosociales de riesgo de consumo de drogas ilícitas en una muestra de estudiantes mexicanos de educación media. Rev Panam Salud Pública. 2008;24(4):223-232.

6. Facundo FRG, Pedrão LJ. Factores de riesgo personales e interpersonales en el consumo drogas ilícitas en adolescentes y jóvenes marginales de bandas juveniles. Rev Lat Am Enfermagem. 2008;16(3):368-374.

7. Morales BN, Plazas M, Sanchez R, et al. Factores de riesgo y de protección relacionados con el consumo de sustancias psicoactivas en estudiantes de enfermería. Rev Latino-Americana Enferm Enferm. 2011;19:673683.

8. Olwerus DA. Aggression in the schools: Bullies and whipping boys. Washington, USA: 1978.

9. Kim MJ, Catalano RF, Haggerty KP, et al. Bullying at elementary school and problem behavior in young adulthood: a study of bullying, violence, and substance use from age 11 to Age 21. Crim Behav Ment Heal. 2011;21(2):136-144.

10. Méndez I, Cerezo F. Bullying y factores de riesgo para la salud en estudiantes de secundaria. Eur J Educ Psychol. 2010;3(2):209-218.

11. McKenna M, Hawk E, Mullen J. Bullying among middle school and high school students--Massachusetts, 2009. MMRWMorb Mortal Wkly Rep. 2011;60(15):465-471.

12. Albores-Gallo L, Sauceda-García JM, Ruiz-Velasco S, et al. El acoso escolar (bullying) y su asociación con trastornos psiquiátricos en una muestra de escolares en México. Salud Publica Mex. 2011;53(3):220-227.

13. Bárcenas-López RM, Curiel-Reyes R, Caballero-Hoyos R, et al. Prevalencia de acoso escolar (bullying) en estudiantes de una secundaria pública. Salud Publica Mex. 2012;54(4):362-363.

14. Rodriguez ES. Relación entre nivel socioeconomico, apoyo social percibido, género y depresión en niños. Rev Psicol y ciencias afines. 2010;27(2):261-275.

15. Romera FEM, Del Rey AR, Ortega RR. Prevalencia y aspectos diferenciales relativos al género del fenómeno bullying en países pobres. Psicothema. 2011;23(4):624-629.

16. Cooper H. Research synthesis and meta-analysis: a step-by-step approach. California: Kinight; 2007.

17. Luk JW, Simons-morton BG. Bullying victimization and substance use among U.S. Adolescents: Mediation by depression. Prev Sci. 2010;11(4):355-359.

18. Wright MF. Cybervictimization and substance use among adolescents: The moderation of perceived social support. $J$ Soc Work Pract Addict. 2016;16(1-2):93-112.

19. Ringwalt $\mathrm{C}$, Shamblen S. Is There an association between adolescent bullying victimization and substance abuse. J Drug Educ. 2012;42(4):447-467.

20. Mitchell KJ, Ybarra M, Finkelhor D. The Relative importance of online victimization in understanding depression, delinquency, and substance use. Child Maltreat. 2007;12(4):314-324.

21. Morris EB, Zhang B, Bondy SJ. Bullying and smoking: Examining the relationships in Ontario adolescents. J Sch Health. 2006;76(9):465-470.

22. Fleming LC, Jacobsen KH. Bullying among middle-school students in low and middle income countries. Health Promot Int. 2009;25(1):73-84

23. Topper LR, Castellanos-Ryan N, Mackie C, et al. Adolescent bullying victimisation and alcohol-related problem behaviour mediated by coping drinking motives over a 12 month period. Addict Behav. 2011;36(12):6-13. 
24. Azagba S. School bullying and susceptibility to smoking among never-tried cigarette smoking students. Prev Med (Baltim). 2016;85:69-73.

25. Carmona-Torres JA, Cangas AJ, Langer ÁI, et al. Acoso escolar y su relación con el consumo de drogas y trastornos alimentarios: comparación entre adolescentes de Chile y España. Behav Psychol/Psicol Conduct. 2015;23(3):507-527.

26. Harlow KC, Roberts R. An Exploration of the relationship between social and psychological factors and being bullied. Child Sch. 2010;32(1):1526.

27. Luukkonen AH, Riala K, Hakko H, et al. Bullying behaviour and substance abuse among underage psychiatric inpatient adolescents. Eur Psychiatry. 2010;25(7):382-389.

28. Kelly EV, Newton NC, Stapinski LA, et al. Suicidality, internalizing problems and externalizing problems among adolescent bullies, victims and bully-victims. Prev Med. 2015;73:100-105.

29. Hertz MF, Everett JS, Barrios L, et al. Association between bullying victimization and health risk behaviors among high school students in the united States. J Sch Health. 2015;85(12):833-842.

30. Forster M, Dyal SR, Baezconde-Garbanati L, et al. Bullying victimization as a mediator of associations between cultural/familial variables, substance use, and depressive symptoms among Hispanic youth. Ethn Health. 2013;18(4):415-432.
31. Litwiller BJ, Brausch AM. Cyber bullying and physical bullying in adolescent suicide: The role of violent behavior and substance use. $J$ Youth Adolesc. 2013;42(5):675-684.

32. Luk JW, Wang J, Simons-Morton BG. The co-occurrence of substance use and bullying behaviors among U.S. adolescents: Understanding demographic characteristics and social influences. J Adolesc. 2012;35(5):1351-1360

33. Niemelä S, Brunstein-Klomek A, Sillanmäki L, et al. Childhood bullying behaviors at age eight and substance use at age 18 among males. A nationwide prospective study. Addict Behav. 2011;36(3):256-260.

34. Russell ST, Ryan C, Toomey RB, et al. Gay, Bisexual, and transgender adolescent school victimization: Implications for young adult health and adjustment. $J$ Sch Health. 2011;81(5):223-230.

35. Sullivan TN, Farrell AD, Kliewer W. Peer victimization in early adolescence: Association between physical and relational victimization and drug use, aggression, and delinquent behaviors among urban middle school students. Dev Psychopathol. 2006;18(1):119-137.

36. Tharp-Taylor S, Haviland A, D'Amico EJ. Victimization from mental and physical bullying and substance use in early adolescence. Addict Behav. 2009;34(6-7):561-567. 